This is an Accepted Manuscript of an article published by Taylor \& Francis in Innovations in Education and Teaching International on 06/01/17, available online: http://www.tandfonline.com/doi/full/10.1080/14703297.2016.1273790 


\title{
Retrospection and reflection: The emerging influence of an institutional professional recognition scheme on professional development and academic practice in a UK university
}

\author{
Hendrik van der Sluis*, Penny Burden and Isabel Huet \\ Centre for Higher Education Research and Practice (CHERP), Kingston University, London, \\ UK
}

Centre for Higher Education Research and Practice (CHERP), Kingston Hill campus, Kingston University, Kingston upon Thames, KT2 7LB

*h.vandersluis@kingston.ac.uk

\begin{abstract}
Raising the quality and profile of teaching and student learning is something universities across the UK are aspiring to achieve in order to maintain reputations. Currently, the UK Professional Standards Framework (UKPSF) provides a standard by which academic staff can gain professional recognition for their academic practice and many UK universities are now offering professional development opportunities via inhouse recognition schemes, based on retrospection and reflection, to enable staff to achieve an HEA Fellowship. This paper provides a case study of one such institutional recognition scheme and discusses the impact it is beginning to have on experienced academics. The findings suggest that recognition schemes contribute to participants' staff development, provide opportunities for the enhancement of practice and that those who participate in the scheme identify value in the reflective process for reconciliation, confirmation of achievements and reinforcing commitment to teaching and/or supporting learning.
\end{abstract}

\section{KEYWORDS}

UKPSF; impact teaching and learning; professional development; recognition scheme; evaluation 


\section{Introduction}

The past 25 years have seen many highly significant developments aimed at raising the professional standing of teaching and learning across higher education in the UK. Organisations such as SEDA (Staff and Educational Development Association), the Higher Education Academy (HEA) and various government initiatives such as the Fund for the Development of Learning and Teaching (FDTL) and the Centres for Excellence in Learning and Teaching (CETL) (Brand, 2007; Wisdom, Lea, \& Parker, 2013) have been instrumental in driving this agenda forwards. Although the funding for most of these initiatives has now ceased, the Higher Education Statistics Agency (HESA) requires universities to include the number of staff 'qualified' to teach in HE in their annual submission of data. This is not something universities can ignore (Spowart, Turner, Shenton, \& Kneale, 2015) and within this context, it is important to understand how the growing number of professional recognition schemes in UK universities is effectively contributing to the professional development of academics in relation to teaching and learning (Hibbert \& Semler, 2015). This paper provides a case study of one institutional scheme to explore the impact on individuals' professional development.

\section{The UK Professional Standards Framework}

The emergence of the UKPSF can be seen through influential policy documents specifically the Dearing Report (NCIHE, 1997) and The Future of Higher Education (DfES, 2003) (cf. Brand, 2007; Lea \& Purcell, 2015; Turner et al., 2013). Dearing (NCIHE, 1997) stimulated the professionalisation of learning and teaching in HE by calling for accredited programmes in learning and teaching to support the professional development of new members of academic staff and through the establishment of what eventually became the HEA. The Future of Higher Education (DfES, 2003) recommended the development of standards that would apply to all members of staff who teach in HE, leading to the first iteration of the UKPSF in 2006. The importance of the revised standards in 2011 gained traction after the Browne Review of HE (Browne, 2010) and the subsequent White Paper Students at the Heart of the System (BIS, 2011), which led to proposals to increase competition amongst Higher Educational Institutions (HEIs). The White Paper developed this notion further by proposing key changes in the way that HE in the UK is funded and argued that the marketisation of HE would drive up teaching quality as students would chose to study at institutions with the best 
reputations for teaching, research and graduate employability (BIS, 2011). The current White Paper, Success as a Knowledge Economy: Teaching Excellence, Social Mobility and Student Choice (BIS, 2016), has highlighted, once more, the importance of teaching quality indicators in the light of student choice but, as Spowart et al. (2015) argue, there is an implicit assumption that recognition for teaching will lead to the enhancement of the student learning experience, which this study attempts to explore further.

\section{Professional Development and Recognition Schemes}

The introduction of the revised UKPSF in 2011, with its four distinct categories of professional standing, meant that the demonstration of professional learning for the purpose of awarding professional status became an important issue. Previously, this learning was demonstrated via accredited taught programmes to stimulate the development of good practice in learning and teaching in HE, primarily aimed at new members of academic staff. Increasingly, colleagues from across the academic community, both new and experienced academics, are participating in institutional recognition schemes (Hibbert \& Semler, 2015).

In common with other UK universities, Kingston University offers an academic development programme to support the professional development of staff who teach and/or support student learning. At the heart of this provision is Kingston's Academic Practice Standards framework (KAPS), an HEAaccredited scheme based on the UKPSF (2011) which provides an opportunity for staff to gain recognition as a Fellow of the HEA within one of the four categories of professional recognition, Associate (AFHEA), Fellow (FHEA), Senior (SFHEA) or Principal Fellow (PFHEA). The KAPS scheme is closely aligned with the requirements of the HEA's direct route to obtaining a fellowship and the main artefact produced by participants is their reflective account of professional practice (APP). In the APP, participants present their evidence in a reflective, personal, individual and scholarly account to demonstrate that they meet the requirements of a particular category, and that they have internalised and understood the UKPSF Dimensions of Practice (DoP) (Lea \& Purcell, 2015; van der Sluis, Burden, \& Huet, 2016; UKPSF, 2015).

Although the UKPSF aims to 'support the initial and continuous professional development' (UKPSF, 2011, p. 2), recognition schemes, such as KAPS, primarily 
support participants in obtaining an HEA fellowship in recognition for their teaching practice. The structure of traditional taught programmes in learning and teaching is front loaded, and enables staff to develop their understanding and practice through exposure to theoretical underpinning and practical training, whereas recognition schemes promote a retrospective, reflective model of professional development, one whereby participants need to demonstrate that they reflect on and interrogate their practice, incorporate the dimensions of the UKPSF and evidence their experiential development of knowledge and competencies (cf. Hibbert \& Semler, 2015; Pilkington, 2013; Thornton, 2014). Staff are required to evidence their engagement with CPD over time; they are not explicitly exposed to new forms of knowledge or theories about learning and teaching as part of the recognition scheme. The relationship between professional development and practice is complex (cf. D'Andrea \& Gosling, 2005), considering the emphasis within the recognition scheme of the APP, and it is important to understand how it contributes to the professional development of academic staff.

Perhaps more importantly is how reflectiveness is situated within the recognition schemes. Although discussed in relation to taught programmes in learning and teaching, the genuine opportunities of reflection and reflective practice in relation to professional learning, which often refers to the work by Donald Schön (2009) amongst others, are questioned (cf. Edwards \& Nicoll, 2006; Macfarlane \& Gourlay, 2009; Nicoll \& Harrison, 2003). Nicoll and Harrison (2003, p. 24) question the use of reflection as a means to enforce and internalise standards, whereby reflectiveness becomes little more than 'matching-up' their practice with a 'prescribed list of competencies'. Edwards and Nicoll (2006, p. 124) question 'persuasive strategies' and espoused theories that are imposed through the use of reflection and standards, marginalising other, and locally more appropriate forms of professional development and knowledge. Macfarlane and Gourlay (2009) raise the appropriateness of reflective practice in staff development programmes which are of limited length and require an assessment by peers, which reduces reflection to a ritualistic exercise instead of empowering individual practices and context. These concerns may apply as well to the recognition schemes. For instance, staff evidence their practice and their reflection on this in an account that is assessed by their peers. Knowing that the APP is going to be 'judged' by their peers, they frequently shy away from reflecting on the more challenging aspect of their role, which might provide more powerful initiators for professional development. The 
'retrospective benchmarking' approach may well provide adequate evidence of mastering the UKPSF DoP (mechanistic approach) but at the expense of the development of ongoing practice which may be messy and/or open-ended yet could lead to significant change that genuinely improves and impacts the student experience.

Another pertinent issue are the institutional strategies within which many recognition schemes have been developed. Many UK universities now offer HEA-accredited recognition schemes similar to KAPS to support staff in gaining fellowship recognition. (HEA, 2015). An increasing number of HEIs are highlighting the importance of possession of an HEA fellowship through key performance indicators (KPI) and are, as the HEA argues, aiming 'towards $100 \%$ of their staff gaining HEA fellowship in recognition of their teaching standards' (UKPSF, 2015, npn). Although this is not the case for all, it is apparent that many institutions are following this path (cf. Hibbert \& Semler, 2015).

Kingston University's Education Strategy has set a target for all academic staff to hold a professional recognition or qualification in learning and teaching by 2018. Achieving an HEA Fellowship is discussed with staff during annual appraisals and possession of an appropriate HEA Fellowship is also an essential component of academic promotion and progression. Institutional support for this is important as it indicates a powerful commitment to this activity; however, this can be seen as a double-edged sword (Burden \& Peat, 2014). As Copeland (2014, p. 7) argues, academic staff should be motivated by professional and 'pedagogical reasons, and not by performance indicators'. Institutional performance indicators stimulating staff development may, in contrast, contrive engagement, therefore diminishing its utilisation in relation to teaching practice, as argued by for instance, D’Andrea and Gosling (2005), Di Napoli (2014) and Peseta (2014) and the findings of Thornton (2014) indicate. They discuss the 'rules of the game' where organisational change may be a product of these interventions but they are, as Peseta (2014, p. 66) argues, 'subject to institutional capture both for good and ill'.

These factors were all key to our interest to investigate KAPS as a case study (Bryman, 2008); to investigate the value of a recognition scheme for participants' professional development and teaching and related academic practices. 


\section{Methods}

\section{Results}

To evaluate the influence of the KAPS scheme on participants' professional development and teaching and related academic practices, a mixed method design was chosen, combining quantitative with qualitative methods (Creswell, 2011). A questionnaire was designed and disseminated amongst the participants. This was combined with semi-structured interviews to fine-grain the generalised results and to enhance the overall confidence of the findings (Bryman, 2008).

The questionnaire was designed with a set of questions to probe the background of those participating in the scheme, followed by two sets of questions investigating the perceived influence of the scheme on their professional development and their teaching and related academic practices, using Likert scale statements. It was administered online and was sent out to 180 participants who had been actively engaged since the initiation of the recognition scheme (from March 2014 to January 2015). The data were analysed with the help of R statistical software. Group comparisons with categorical variables were made using the Fisher's Exact Test (statistically significant if $p<0.05$ ), a nonparametric alternative to the Chi-Square Test, as some of the parametric assumptions of the latter could not be met (Boslaugh \& Watters, 2012).

The design, sample size and data analysis of the semi-structured interviews were guided by the Interpretative Phenomenological Analysis (IPA) methodology to investigate what meaning participants attached to obtaining a fellowship of the HEA through KAPS in relation to their professional development and teaching practices. IPA in brief, is regarded as an appropriate research approach to investigate experiences and meaningmaking in relation to a particular phenomenon and context, using a relative small purposeful sample (cf. Larkin \& Thompson, 2012; Smith, Flowers, \& Larkin, 2009). Considering KAPS is designed to support experienced members of staff, a purposeful sample of six senior academics, with managerial responsibility, was selected. All participants were interviewed around six months after they obtained their SFHEA to ensure sufficient time for reflection on changes to professional practice and development. In accordance with the IPA research methodology, the interview 
transcripts were analysed using thematic coding to draw together common themes, shared experiences and interpretations, with the help of qualitative data analysis (QDA) software NVivo (Larkin \& Thompson, 2012; Smith et al., 2009).

\section{Background of the participants}

The questionnaire ultimately captured a $52 \%$ response rate, regarded as reasonably satisfactory for a questionnaire (cf. Bryman, 2008). The majority of the respondents were at a senior stage of their academic career, where the staff categories Associate Professor (39\%) and Senior Lecturer (34\%) accounted for more than two-thirds. This reflects the objective of the KAPS scheme to offer professional development for experienced members of staff leading to a fellowship of the HEA. The majority (56\%) of the respondents were aiming for a SFHEA, 13\% for FHEA, 6\% for PFHEA and 4\% for AFHEA.

The six interviewees were selected from different disciplinary backgrounds and were either Associate Professors or Senior Lecturers, with managerial and/or leadership responsibilities such as Head of School and/or Course Director.

\section{Influence on participants' professional development}

The majority of the respondents agreed that their participation in KAPS had stimulated their professional development, see Table 1 . The majority of the respondents (71\%) agreed that it had encouraged them to read more about HE and related educational research; to collaborate with peers $(65 \%)$; to evaluate their teaching (63\%); attend relevant workshops (69\%); become more aware of quality enhancement and assurance (68\%); and felt stimulated to disseminate their own innovative teaching and learning practice $(58 \%)$.

Table 01: Influence on professional development

The KAPS application process contributed to my professional development by:

\begin{tabular}{|l|l|l|l|l|}
\hline & $\begin{array}{l}\text { Disagree } \\
(\%)\end{array}$ & $\begin{array}{l}\text { Not sure } \\
(\%)\end{array}$ & $\begin{array}{l}\text { Agree } \\
(\%)\end{array}$ & $\begin{array}{l}\text { NR/NA } \\
(\%)\end{array}$ \\
\hline
\end{tabular}




\begin{tabular}{|l|l|l|l|l|}
\hline $\begin{array}{l}\text { reading literature related to HE and/or educational } \\
\text { research }\end{array}$ & 5 & 4 & 71 & 19 \\
\hline collaborating with my peers & 12 & 5 & 65 & 18 \\
\hline evaluating my teaching & 8 & 5 & 63 & 24 \\
\hline $\begin{array}{l}\text { disseminating innovative teaching and learning } \\
\text { practice }\end{array}$ & 9 & 4 & 58 & 29 \\
\hline $\begin{array}{l}\text { attending internal or external workshops, seminars, } \\
\text { etc., related to HE }\end{array}$ & 5 & 2 & 69 & 24 \\
\hline $\begin{array}{l}\text { being aware of the implications related to quality } \\
\text { enhancement and quality assurance }\end{array}$ & 9 & 3 & 68 & 20 \\
\hline
\end{tabular}

Considering the difference in role and responsibilities between UKPSF descriptors 2 and 3 , it could be expected that there may have been some variation in the responses between the two categories, especially with regard to disseminating innovative practice, which could be regarded as more applicable for the latter. However, a comparison by question, using the Fisher's Exact Test was not significant, indicated that there was no difference in the perceived influence of how KAPS contributed to professional development within the majority of the sample group, see Table 2.

Table 02: Influence on professional development by FHEA and SFHEA

\begin{tabular}{|c|c|c|c|c|c|}
\hline \multicolumn{6}{|c|}{ The KAPS application process contributed to my professional development by: } \\
\hline & & $\begin{array}{l}\text { Disagree } \\
\text { (n) }\end{array}$ & $\begin{array}{l}\text { Not sure } \\
\text { (n) }\end{array}$ & $\begin{array}{l}\text { Agree } \\
(n)\end{array}$ & $\begin{array}{l}\text { Fisher's } \\
\text { Exact Test } \\
\text { (p-value) }\end{array}$ \\
\hline \multirow{2}{*}{$\begin{array}{l}\text { reading literature related to } \mathrm{HE} \text { and/or } \\
\text { educational research }\end{array}$} & FHEA & 1 & 1 & 9 & \multirow[b]{2}{*}{0.36} \\
\hline & SFHEA & 2 & 2 & 38 & \\
\hline \multirow[b]{2}{*}{ collaborating with my peers } & FHEA & 2 & 1 & 8 & \multirow[b]{2}{*}{0.86} \\
\hline & SFHEA & 6 & 5 & 32 & \\
\hline \multirow[b]{2}{*}{ evaluating my teaching } & FHEA & 0 & 0 & 11 & \multirow[b]{2}{*}{0.73} \\
\hline & SFHEA & 4 & 2 & 35 & \\
\hline
\end{tabular}




\begin{tabular}{|c|c|c|c|c|c|}
\hline \multirow{2}{*}{$\begin{array}{l}\text { disseminating innovative teaching and } \\
\text { learning practice }\end{array}$} & FHEA & 1 & 0 & 9 & \multirow[b]{2}{*}{0.82} \\
\hline & SFHEA & 5 & 4 & 28 & \\
\hline \multirow{2}{*}{$\begin{array}{l}\text { attending internal or external workshops, } \\
\text { seminars, etc., related to HE }\end{array}$} & FHEA & 0 & 0 & 11 & \multirow[b]{2}{*}{1.00} \\
\hline & SFHEA & 3 & 1 & 35 & \\
\hline \multirow{2}{*}{$\begin{array}{l}\text { being aware of the implications related to } \\
\text { quality enhancement and quality assurance }\end{array}$} & FHEA & 0 & 0 & 11 & \multirow[b]{2}{*}{0.73} \\
\hline & SFHEA & 4 & 2 & 36 & \\
\hline
\end{tabular}

The interviews supported the finding that the KAPS scheme had contributed to respondents' professional development. As part of the application process, participants had to collate their past and recent CPD with a focus on teaching and learning in HE which was perceived as refreshing and stimulating (cf. UKPSF, 2011). Most interviewees stated they had undertaken various forms of professional development throughout their careers, usually related to their disciplinary or professional practice. Clearly, participation in the KAPS scheme had raised awareness and reaffirmed the importance of professional development related to teaching and learning.

Reflecting on the various forms of professional development undertaken over time and the impact of this in relation to the interviewees' practices had reinforced participants' investment and commitment to teaching and supporting learning in HE.

We engage with so many things during our professional activity that we lose track of all the things, so it's made me more adept at recording, a more structured recording, of all the things that I am doing and what the implications of those are really.

Finally, the reflection on the CPD undertaken, within the context of the scholarship of teaching and learning, appeared to emphasise the wider HE context, particularly the role of the HEA and the UKPSF as being the current drivers for the recognition of teaching in HE.

It made me much more aware of the bigger picture, the role of the HEA which was something I wasn't really that aware of before.

\section{Influence on professional practice and setting}

A little over half of the respondents agreed that as a result of applying for a fellowship, they made changes to their teaching practices, see Table 3. When asked if they had made substantial changes to practice, in the form of redesigning a programme or 
module, less than half of the respondents (44\%) agreed and almost a fourth (23\%) disagreed which indicates that participation in a recognition scheme may have stimulated more small-scale than significant changes to existing teaching practices. It should be noted that the respondents were at different stages of their fellowship application at the time of the questionnaire, and the extent of the changes to practice may not have been fully understood at this time.

Table 03: Influence on teaching and/or supporting learning practice As a result of my fellowship application I have made changes to my practice in respect of:

\begin{tabular}{|l|l|l|l|l|}
\hline & $\begin{array}{l}\text { Disagree } \\
(\%)\end{array}$ & $\begin{array}{l}\text { Not sure } \\
(\%)\end{array}$ & $\begin{array}{l}\text { Agree } \\
(\%)\end{array}$ & $\begin{array}{l}\text { NR/NA } \\
(\%)\end{array}$ \\
\hline the design and planning of learning activities & 16 & 8 & 52 & 25 \\
\hline teaching and/or supporting students' learning & 17 & 8 & 53 & 23 \\
\hline assessment and giving feedback to students & 14 & 5 & 57 & 24 \\
\hline the use of technology to support students' learning & 18 & 6 & 53 & 23 \\
\hline the (re)design of programmes of study or modules & 23 & 8 & 44 & 26 \\
\hline
\end{tabular}

Besides enhancing the areas of activity, the UKPSF aims to contribute to a wider professional setting. Around half of the respondents agreed that participation in the recognition scheme had resulted in changes with regard to the UKPSF professional values, such as becoming more inclusive and attentive to diverse learning needs (49\%) see Table 4. A little more than half of the respondents agreed that they made changes with regard to supporting and mentoring colleagues (53\%). Moreover, less than a third (32\%) of the respondents felt that they had been able to make changes at a departmental or institutional level, which may suggest that most changes have not taken place outside the respondents' direct sphere of influence.

Table 04: Influence on professional values and setting

As a result of my fellowship application I have made changes to my practice in respect of: 


\begin{tabular}{|l|l|l|l|l|}
\hline & $\begin{array}{l}\text { Disagree } \\
(\%)\end{array}$ & $\begin{array}{l}\text { Not sure } \\
(\%)\end{array}$ & $\begin{array}{l}\text { Agree } \\
(\%)\end{array}$ & $\begin{array}{l}\text { NR/NA } \\
(\%)\end{array}$ \\
\hline $\begin{array}{l}\text { being more inclusive to individual and/or diverse } \\
\text { learning needs }\end{array}$ & 15 & 12 & 49 & 24 \\
\hline ensuring greater participation in higher education & 22 & 12 & 42 & 25 \\
\hline supporting and mentoring colleagues & 15 & 8 & 53 & 25 \\
\hline departmental or institutional change & 19 & 17 & 32 & 31 \\
\hline
\end{tabular}

Considering the differences in role and responsibilities between the UKPSF descriptors 2 and 3, a variation within the sample group could be expected with regard to the probed teaching practices, professional values and setting. A comparison of respondents applying for FHEA and SFHEA was not found significantly different for any of the questions, see Table 5. This needs to be interpreted against the objectives of the recognition scheme. Although participants chose to apply for descriptor 2, they are experienced educators, having worked in HE for more than 3 years. Their motivation for doing so may have been more to align themselves with institutional objectives than a genuine desire to develop their practice.

Table 05: Changes to professional practice between SFHEA and FHEA

\begin{tabular}{|c|c|c|c|c|c|}
\hline \multicolumn{6}{|c|}{ As a result of my fellowship application I have made changes to my practice in respect of: } \\
\hline & & $\begin{array}{l}\text { Disagree } \\
\text { (n) }\end{array}$ & $\begin{array}{l}\text { Not sure } \\
(\mathbf{n})\end{array}$ & $\begin{array}{l}\text { Agree } \\
(\mathbf{n})\end{array}$ & $\begin{array}{l}\text { Fisher's } \\
\text { Exact Test } \\
\text { (p-value) }\end{array}$ \\
\hline \multirow{2}{*}{$\begin{array}{l}\text { the design and planning of learning } \\
\text { activities }\end{array}$} & FHEA & 1 & 0 & 10 & \multirow[b]{2}{*}{0.33} \\
\hline & SFHEA & 8 & 5 & 26 & \\
\hline \multirow{2}{*}{$\begin{array}{l}\text { teaching and/or supporting students' } \\
\text { learning }\end{array}$} & FHEA & 1 & 0 & 10 & \multirow[b]{2}{*}{0.43} \\
\hline & SFHEA & 9 & 4 & 27 & \\
\hline \multirow{2}{*}{$\begin{array}{l}\text { assessment and giving feedback to } \\
\text { students }\end{array}$} & FHEA & 1 & 0 & 10 & \multirow[b]{2}{*}{0.70} \\
\hline & SFHEA & 7 & 3 & 29 & \\
\hline the use of technology to support & FHEA & 0 & 1 & 10 & 0.23 \\
\hline
\end{tabular}




\begin{tabular}{|c|c|c|c|c|c|}
\hline students' learning & SFHEA & 9 & 3 & 28 & \\
\hline \multirow{2}{*}{$\begin{array}{l}\text { the (re)design of programmes of study } \\
\text { or modules }\end{array}$} & FHEA & 1 & 1 & 7 & \multirow[b]{2}{*}{0.41} \\
\hline & SFHEA & 13 & 4 & 22 & \\
\hline \multirow{2}{*}{$\begin{array}{l}\text { being more inclusive to individual } \\
\text { and/or diverse learning needs }\end{array}$} & FHEA & 1 & 1 & 9 & \multirow[b]{2}{*}{0.61} \\
\hline & SFHEA & 7 & 8 & 24 & \\
\hline \multirow{2}{*}{$\begin{array}{l}\text { ensuring greater participation in higher } \\
\text { education }\end{array}$} & FHEA & 1 & 2 & 7 & \multirow[b]{2}{*}{0.88} \\
\hline & SFHEA & 9 & 8 & 22 & \\
\hline \multirow[b]{2}{*}{ supporting and mentoring colleagues } & FHEA & 1 & 1 & 7 & \multirow[b]{2}{*}{0.86} \\
\hline & SFHEA & 9 & 5 & 26 & \\
\hline \multirow[b]{2}{*}{ departmental or institutional change } & FHEA & 1 & 2 & 4 & \multirow[b]{2}{*}{0.87} \\
\hline & SFHEA & 10 & 11 & 15 & \\
\hline
\end{tabular}

The interviewees saw the importance of the KAPS scheme less in relation to their teaching practices, and more in relation to their professional role and responsibilities. Obtaining an HEA Fellowship had reaffirmed interviewees' experiences, expertise and reputation for teaching and supporting learning. It was valued as a reconciliation of their career trajectories, milestones and commitment than producing new insights, developing new knowledge and/or competencies, or functioning as a change agent and stimulating innovative practices.

"[...] probably the most practical impact on teaching and working with students were the two workshops that I did [...] it was quite a helpful stimulus to do those"

"It didn't produce for me a huge number of insights if you like in terms of how I might do things practically. [...] it tended to reinforce some kind of learning needs that I kind of probably knew I had and it helped to think how I might do things differently [by] looking back"

Being in senior roles within the institution, the interviewees felt the responsibility to carry forward the ethos of the UKPSF and institutional policies, and set an example within their school and/or faculty. Having been one of the first to obtain a 
fellowship through the recognition scheme reinforced the interviewees in their role of mentor and keen supporter of learning and teaching.

"I suppose my previous experience enables me to support and guide others with regards to education and teaching. I suppose going through the [recognition] scheme and certainly when I got the Senior Fellow [provided further credibility]"

\section{Conclusion and discussion}

Although the results need to be considered within the context of the case study (Bryman, 2008), they suggest that the KAPS recognition scheme contributes to various dimensions of professional development. Despite the concerns expressed above about the retrospective and reflective nature of the professional development (cf. Macfarlane \& Gourlay, 2009), and its main objective of obtaining a fellowship, the recognition scheme does stimulate an engagement with the scholarship of teaching and learning and other professional development activities including CPD workshops, collaboration with peers and sharing of innovative practice. Moreover, as the interviewees indicated, obtaining a fellowship through a recognition scheme brought into focus the importance of the UKPSF as a driver for recognition of professional practice within the HE sector (cf. Turner et al., 2013).

Furthermore, the results indicate that respondents have made changes to their teaching and related practice as a result of participating in a recognition scheme. This suggests that despite the retrospective and reflective professional development orientation of this recognition scheme (cf. Edwards \& Nicoll, 2006; Hibbert \& Semler, 2015), and the contriving institutional policies reinforcing or policing engagement (cf. Di Napoli, 2014; Peseta, 2014), engagement with the process does carry forward opportunities for the enhancement of current and future educational practices. Nonetheless, at this stage, the findings suggest rather smaller and local interventions than considerable changes at a programme or departmental level or, as the interviewees indicated, the value of a fellowship was not found in its direct application to teaching practices, but in its reconciliation, confirmation of achievements and reinforcing commitment to teaching and/or supporting learning (cf. Thornton, 2014). 
The findings of our investigation are enabling a better understanding of the impact of our recognition scheme and are being used to shape provision as we continue to develop the scheme (cf. Bamber \& Stefani, 2015). From these findings, we are now constructing a broad CPD framework, structured around academic activities - learning and teaching, research, leadership and management - connecting needs at different levels rather than simply focusing on the needs of new academics and leaving more senior, experienced academics to find their own way through the scheme. This in turn will lead to further investigation, particularly in the light of the forthcoming UK Teaching Excellence Framework (BIS, 2016), its impact on institutions and on the development of professional recognition schemes.

\section{Notes on contributors}

Hendrik van der Sluis is a lecturer, Penny Burden is an associate professor and Isabel Huet is a senior lecturer, all at the Centre for Higher Education Research and Practice (CHERP) at Kingston University, London.

Hendrik van der Sluis is a lecturer of Learning and Teaching in Higher Education. Within related roles in Higher and Further Education in the United Kingdom and the Netherlands, he has taught, supported learning and developed the learning environment in a variety of settings. His research interests have followed his professional roles and include widening participation, student attainment, technology-enhanced learning and professional development. His current research interest focuses on the professionalisation of teaching and learning in HE, and the notion of identities, structure, agency and practice.

Penny Burden is an associate professor and director of Kingston's Academic Practice Standards framework (KAPS). She has worked in academic development for over 20 years in several UK higher education institutions and currently leads on the development and implementation of the KAPS scheme and CPD activity across the University. Penny is an external examiner/assessor at several UK universities, co-chair of the South East Network of Academic Developers and an active member of SEDA.

Isabel Huet is a senior lecturer and manager of the Academic Development Associate Research Scheme (SADRAS) at Kingston University. She has been involved in 
academic development, both nationally and internationally, since 2005 and has been engaged in Higher Education research since 2000. She has participated in several EUfunded projects on improving the quality of teaching and learning and curriculum design in Higher Education. Her research interests include academic development, research-based education, doctoral education and pedagogical research.

\section{References}

Bamber, V. and Stefani, L., (2015). 'Taking up the challenge of evidencing value in educational development: from theory to practice'. International Journal for Academic Development, 21(3), pp.1-13.

BIS (2011). Higher Education: Students at the Heart of the System. Department for Business Innovation \& Skills, London: HMSO.

BIS (2016). Success as a Knowledge Economy: Teaching Excellence, Social Mobility and Students Choice. Department for Business Innovation \& Skills, London: HMSO.

Boslaugh, S. and Watters, P.A., (2012). Statistics in a nutshell. Cambridge: O'Reilly. Brand, A. (2007), 'The long and winding road: professional development in further and higher education', Journal of Further and Higher Education, 31(1), pp.7-16.

Browne, J. (2010). Securing a sustainable future for higher education. An Independent review of Higher Education funding and student finance, London: HMSO.

Bryman, A. (2008), Social Research (3rd ed.), New York, Oxford University Press.

Copeland, R. (2014) Beyond the Consumerist Agenda: Teaching quality and the 'student experience' in higher education, London: University and College Union.

Creswell, J. W. (2011). Controversies in mixed methods research, in Denzin, N.K. and Lincoln, Y.S. (Eds.). The SAGE handbook of qualitative research. London: Sage, pp.269284.

D'Andrea, V. and Gosling, D. (2005). Improving Teaching And Learning In Higher Education: A Whole Institution Approach: A whole institute approach. Maidenhead: McGraw-Hill International.

Di Napoli, R. (2014). 'Value gaming and political ontology: between resistance and compliance in academic development'. International Journal for Academic Development, 19(1), pp.4-11.

DfES (2003). The future of higher education, Department for Education and Skills, London: HMSO. 
Edwards, R. and Nicoll, K. (2006). 'Expertise, competence and reflection in the rhetoric of professional development'. British Educational Research Journal, 32(1), pp.115-131.

HEA (2015). HEA accredits its 100th institutional CPD scheme. Academic Update June 2015, Higher Education Academy, 17 June 2015, available at: http://highereducationacademy.newsweaver.com/newsletter/1rwz6juoaug.

Hibbert, P., and Semler, M. (2015). 'Faculty development in teaching and learning: the UK framework and current debates'. Innovations in Education and Teaching International, 53(6), pp.1-11.

Larkin, M and Thompson, A (2012), 'Interpretative phenomenological analysis', in A Thompson and D Harper (eds.), Qualitative research methods in mental health and psychotherapy: a guide for students and practitioners. John Wiley, Oxford, pp.99-116.

Lea, J. and Purcell, N. (2015) Introduction: The scholarship of teaching and learning, the Higher Education Academy, and the UK Professional Standards Framework. In Lea, J. (Ed) Enhancing learning and teaching in higher education: Engaging with the dimensions of practice, Maidenhead: Open University Press, pp.1-16.

Locke, W. (2014) Shifting academic careers: implications for enhancing professionalism in teaching and supporting learning. York: The Higher Education Academy

Macfarlane, B., and Gourlay, L. (2009). 'The reflection game: Enacting the penitent self'. Teaching in Higher Education, 14(4), pp.455-459.

NCIHE (1997). The Dearing Report. Higher Education in the learning society, London: HMSO.

Nicoll, K. and Harrison, R. (2003). 'Constructing the good teacher in higher education: the discursive work of standards'. Studies in Continuing Education, 25(1), pp.23-35.

Peseta, T.L. (2014). 'Agency and stewardship in academic development: the problem of speaking truth to power'. International Journal for Academic Development, 19(1), pp.65-69.

Pilkington, R. (2013) 'Professional dialogues: exploring an alternative means of assessing the professional learning of experienced HE academics'. International Journal for Academic Development, 18(3), pp.251-263.

Purcell, N. (2012). The UK professional standards framework for teaching and supporting learning in higher education. Educational Developments, 13(1), pp.6-11.

Schön, D. A. (2009). The reflective practitioner: how professionals think in action. Aldershot: Ashgate

Smith, J.A., Flowers, P., and Larkin, M. (2009). Interpretative Phenomenological Analysis: Theory Method and Research. London: Sage 
Spowart, L., Turner, R., Shenton, D. and Kneale, P., (2015). 'But I've been teaching for 20 years...': encouraging teaching accreditation for experienced staff working in higher education. International Journal for Academic Development, 21(3), pp.1-13.

Turner, N., Oliver, M., McKenna, C., Hughes, J., Smith, H., Deepwell, F. and Strives, L. (2013). Measuring the impact of the UK Professional Standards Framework for Teaching and Supporting Learning (UKPSF). Staff and Educational Development Association and the Higher Education Academy. York: The Higher Education Academy.

Thornton, T., (2014). Professional recognition: promoting recognition through the Higher Education Academy in a UK higher education institution. Tertiary Education and Management, 20(3), pp.225-238.

UKPSF (2011). The UK Professional Standards Framework for teaching and supporting learning in higher education. Higher Education Academy, York: The Higher Education Academy, available at: http://www.heacademy.ac.uk/ukpsf.

UKPSF (2014). Fellowship of the Higher Education Academy. Code of Practice. Higher Education Academy. York: The Higher Education Academy, available at:http://www.heacademy.ac.uk/assets/documents/aboutus/Code_Of_Practice.pdf.

UKPSF (2015). UK Professional Standards Framework (UKPSF). The Higher Education Academy, York: The Higher Education Academy, available at: https://www.heacademy.ac.uk/professional-recognition.

van der Sluis, H., Burden, P. and Huet, I. (2016), 'The evaluation of an institutional UKPSF recognition scheme'. Educational Developments, 17(1), pp.5-9.

Wisdom, J., Lea, J. and Parker, P. (2013). A short history of SEDA, Staff and Educational Development Association. London: SEDA, available at, http://www.seda.ac.uk/resources/files/SEDA\%20Short\%20History_WEB\%20v2.pdf. 